\title{
Luteal function and oestrus in gilts treated with a synthetic analogue of prostaglandin F-2 $\alpha$ (ICI 79,939) at various times during the oestrous cycle*
}

\author{
H. D. Guthrie† and C. Polge \\ A.R.C. Unit of Reproductive Physiology and Biochemistry, Animal Research Station, \\ 307 Huntingdon Road, Cambridge CB3 OJQ, U.K.
}

Treatment of cattle with various doses of prostaglandin (PG) F-2 $\alpha$ by subcutaneous injection (Lauderdale, 1972) or by nonsurgical intrauterine injection (Rowson, Tervit \& Brand, 1972; Liehr, Marion \& Olson, 1972; Louis, Hafs \& Morrow, 1972) induces luteal regression and allows oestrus to occur if initiated after Days 3 or 4 of the oestrous cycle. The oestrous cycle of the mare can also be shortened by administration of PGF-2 $\alpha$ (Douglas \& Ginther, 1972). Because the presence of the uterus is required for normal cyclic function in the pig (Anderson, Bland \& Melampy, 1969), the effects of a synthetic analogue of PGF-2 $\alpha$, ICI 79,939, on luteal function and oestrus in gilts was investigated.

In Exp. 1, 46 mature gilts were each given a single i.m. injection of ICI 79,939 in $0.9 \%(\mathrm{w} / \mathrm{v}) \mathrm{NaCl}$ solution on one day between Days 7 and 12 of the cycle (Day $0=$ day of oestrus). Blood was collected a few minutes before and 24 and $48 \mathrm{hr}$ after the injection from gilts treated on Days 10,11 or 12 and plasma progesterone was measured to monitor luteal function by a competitive proteinbinding assay as described by Henricks, Guthrie \& Handlin (1972) and Seamark, Moor \& McIntosh (1974). The gilts were exposed to a vasectomized boar once daily to check for the occurrence of oestrus. The proportion of animals exhibiting a positive oestrous response in the various treatment groups was assessed by $\chi^{2}$ analysis (Steel \& Torrie, 1960). Plasma progesterone concentrations were subjected to analysis of variance as a split plot over time or a multivariate analysis (Steel \& Torrie, 1960; Gill \& Hafs, 1971). A probability of $\leqslant 5 \%$ was considered significant.

A positive oestrous response was defined as oestrus occurring 5-7 days after the first injection of ICI 79,939. As shown in Table 1, none of the gilts injected before Day 11 of the cycle gave a positive oestrous response, but treatment with doses of 0.25 or $0.5 \mathrm{mg}$ on Day 12 had a significant effect in about $34 \%$ of the gilts. A significant decline in plasma progesterone concentration occurred by $24 \mathrm{hr}$ after the injection, but the single dose was not adequate in most cases to cause complete luteal regression.

In Exp. 2, 57 gilts were used in a $3 \times 3$ factorial experiment consisting of three injection schedules designed to vary the period of treatment with ICI 79,939 and starting on Days 8, 10 or 12 of the oestrous cycle (Table 2). Each injection consisted of $0.5 \mathrm{mg}$ ICI 79,939. Blood samples were collected as shown in Table 2.

The timing of the treatment significantly affected the number of positive responses, which were $0,27 \cdot 8$ and $94.4 \%$ for the Day-8, -10 and -12 groups, respectively. In the Day-10 group, extension of treatment to Day 11 by 4 injections of ICI 79,939 significantly increased the proportion of animals exhibiting a positive response.

Plasma progesterone concentrations after ICI 79,939 treatment are shown in Table 2. Concentrations had decreased significantly in each of the Day-8, -10 and -12 treatment groups by $12 \mathrm{hr}$ after the first injection. In all three Day- 8 groups the concentrations had increased by $24 \mathrm{hr}$ and remained high in spite of continued injections of ICI 79,939.

In the Day-10 groups luteal function was partly restored by $24 \mathrm{hr}$ when ICI 79,939 was not injected at $12 \mathrm{hr}$, but the second injection at $24 \mathrm{hr}$ caused another decline in plasma progesterone

* Reprint requests to Dr C. Polge.

$\dagger$ Present address: U.S,D.A., A.R.S., Beltsville Agricultural Research Center, Beltsville, Maryland 20705, U.S.A. 
Table 1. The return of gilts to oestrus after a single injection of ICI 79,939 during the luteal phase of the oestrous cycle

\begin{tabular}{|c|c|c|c|c|c|}
\hline \multirow{3}{*}{$\begin{array}{c}\text { Day of } \\
\text { treatment }\end{array}$} & \multirow{3}{*}{$\begin{array}{c}\text { Dose of } \\
\text { ICI } 79,939 \\
\text { (mg) }\end{array}$} & \multicolumn{4}{|c|}{ No. of gilts } \\
\hline & & \multirow[b]{2}{*}{ Treated } & \multicolumn{3}{|c|}{ Oestrous response } \\
\hline & & & Positive $\nmid$ & Normal cycle & Delayed $\ddagger$ \\
\hline $7-9$ & $0 \cdot 5-1 \cdot 0$ & $4^{*}$ & 0 & 3 & 0 \\
\hline 10 & 0.5 & 4 & 0 & 4 & 0 \\
\hline 11 & 0.5 & 4 & 2 & 2 & 0 \\
\hline 12 & nil & 8 & 1 & 7 & 0 \\
\hline 12 & $0 \cdot 125$ & 6 & 0 & 4 & 2 \\
\hline 12 & 0.25 & 6 & 2 & 4 & 0 \\
\hline 12 & 0.5 & $12^{*}$ & 4 & 5 & 2 \\
\hline 12 & 1.0 & 2 & 2 & 0 & 0 \\
\hline
\end{tabular}

Table 2. Oestrous response and plasma progesterone concentrations (mean \pm S.E.M.) after treatment of gilts with ICI 79,939 starting on Days 8, 10, or 12 of the oestrous cycle

\begin{tabular}{|c|c|c|c|c|c|c|c|c|c|c|}
\hline \multirow{3}{*}{$\begin{array}{l}\text { Day } \\
\text { reatment } \\
\text { started }\end{array}$} & \multirow{3}{*}{$\begin{array}{l}\text { Time of } \\
\text { injection } \\
\text { (hr) }\end{array}$} & \multicolumn{3}{|c|}{ No. of gilts } & & & & & & \\
\hline & & \multirow[b]{2}{*}{ Treated } & \multirow{2}{*}{$\begin{array}{l}\text { In oestrus } \\
\text { within } \\
5-7 \text { days }\end{array}$} & \multirow{2}{*}{$\begin{array}{c}\text { Oestrus } \\
\text { delayed } \dagger\end{array}$} & \multicolumn{6}{|c|}{ Plasma progesterone $(\mathrm{ng} / \mathrm{ml})$} \\
\hline & & & & & $0 \mathrm{hr}$ & $12 \mathrm{hr}$ & $24 \mathrm{hr}$ & $36 \mathrm{hr}$ & $48 \mathrm{hr}$ & $72 \mathrm{hr}$ \\
\hline \multirow[t]{6}{*}{8} & 0,12 & 6 & 0 & 0 & $\begin{array}{r}18.4 \\
+1.7\end{array}$ & $\begin{array}{r}12.8 \\
+1.5\end{array}$ & $\begin{array}{r}14.2 \\
+2.0\end{array}$ & & $\begin{array}{r}20.9 \\
+1.6\end{array}$ & \\
\hline & 0,24 & $7^{*}$ & 0 & 1 & $20 \cdot 6$ & $13 \cdot 1$ & $18 \cdot 1$ & $18 \cdot 2$ & 19.9 & $25 \cdot 5$ \\
\hline & & & & & $\pm 2 \cdot 2$ & \pm 1.0 & $\pm 2 \cdot 2$ & $\pm 2 \cdot 0$ & \pm 2.0 & $\pm 2 \cdot 2$ \\
\hline & $0,12,24,36$ & $7^{*}$ & $\mathbf{0}$ & 0 & 17.9 & $13 \cdot 2$ & $16 \cdot 2$ & $16 \cdot 3$ & $18 \cdot 2$ & $21 \cdot 6$ \\
\hline & & & & & $\pm 2 \cdot 4$ & $\pm 1 \cdot 6$ & $\pm 1 \cdot 0$ & $\pm 2 \cdot 2$ & $\pm 2 \cdot 7$ & $\pm 4 \cdot 2$ \\
\hline & Combined & 18 & 0 & 1 & $18 \cdot 9$ & $13 \cdot 1$ & $16 \cdot 1$ & $17 \cdot 2$ & $19 \cdot 7$ & $23 \cdot 5$ \\
\hline \multirow[t]{7}{*}{10} & 0,12 & 6 & 0 & 2 & $24 \cdot 4$ & $16 \cdot 4$ & $14 \cdot 0$ & & $17 \cdot 6$ & \\
\hline & & & & & $\pm 2 \cdot 4$ & \pm 1.8 & $\pm 2 \cdot 7$ & & $\pm 3 \cdot 7$ & \\
\hline & 0,24 & 6 & 1 & $\mathbf{0}$ & $30 \cdot 3$ & $14 \cdot 1$ & $19 \cdot 3$ & $10 \cdot 7$ & $12 \cdot 1$ & $12 \cdot 8$ \\
\hline & & & & & $\pm 4 \cdot 2$ & $\pm 2 \cdot 0$ & $\pm 2 \cdot 0$ & $\pm 3 \cdot 2$ & $\pm 3 \cdot 3$ & \pm 3.0 \\
\hline & $0,12,24,36$ & 6 & 4 & 0 & $27 \cdot 6$ & $19 \cdot 0$ & $16 \cdot 3$ & $14 \cdot 2$ & 9.8 & 8.8 \\
\hline & & & & & \pm 3.9 & $\pm 2 \cdot 9$ & $\pm 4 \cdot 9$ & $\pm 5 \cdot 8$ & $\pm 5 \cdot 8$ & $\pm 5 \cdot 4$ \\
\hline & Combined & 18 & 5 & 2 & $27 \cdot 4$ & $16 \cdot 5$ & $16 \cdot 5$ & $12 \cdot 4$ & $13 \cdot 1$ & $10 \cdot 8$ \\
\hline \multirow[t]{7}{*}{12} & 0,12 & $7^{*}$ & 5 & 1 & $30 \cdot 7$ & $11 \cdot 7$ & $4 \cdot 6$ & & $2 \cdot 7$ & \\
\hline & & & & & $\pm 2 \cdot 1$ & \pm 1.8 & $\pm 1 \cdot 5$ & & $\pm 2 \cdot 0$ & \\
\hline & 0,24 & 6 & 6 & 0 & $29 \cdot 7$ & $8 \cdot 7$ & 6.8 & 2.0 & 0.8 & 0.5 \\
\hline & & & & & $\pm 3 \cdot 1$ & $\pm 1 \cdot 4$ & $\pm 2 \cdot 0$ & \pm 0.4 & \pm 0.1 & \pm 0.1 \\
\hline & $0,12,24,36$ & 6 & 6 & 0 & $30 \cdot 4$ & 9.7 & $2 \cdot 8$ & $1 \cdot 5$ & 0.9 & 0.6 \\
\hline & & & & & $\pm 4 \cdot 0$ & \pm 2.9 & \pm 0.8 & \pm 0.3 & \pm 0.1 & \pm 0.1 \\
\hline & Combined & 18 & 17 & 1 & $30 \cdot 3$ & 10.0 & $5 \cdot 0$ & $1 \cdot 7$ & 1.5 & 0.5 \\
\hline
\end{tabular}

* One gilt died during treatment, data excluded.

$\dagger 3$ or more days longer than control cycle.

concentration, although only one gilt exhibited complete luteal regression and a positive oestrous response. Four injections at $12 \mathrm{hr}$ intervals caused plasma progesterone concentrations to decline to $2.5 \mathrm{ng} / \mathrm{ml}$ or less by $48 \mathrm{hr}$ in 4 of 6 gilts. Plasma progesterone concentrations remained high in the other 2 gilts with 15.0 and $36.5 \mathrm{ng} / \mathrm{ml}$ at $48 \mathrm{hr}$ and the gilts had oestrous cycles of 20 and 21 days. 
Very low progesterone concentrations were found in 17 gilts at $48 \mathrm{hr}$ in the Day-12 group; the one gilt that did not respond had a progesterone concentration of $12.8 \mathrm{ng} / \mathrm{ml}$ at $48 \mathrm{hr}$ and an oestrous cycle of 28 days.

The age of the corpora lutea (CL) when the analogue was injected appeared to be the critical factor in determining whether luteal regression would occur; maximum sensitivity seemed to be achieved when the $C L$ were about 10 days old. In gilts in which complete luteal regression was induced, the onset of oestrus occurred 5-7 days after the initiation of treatment. This interval is similar to that observed between the onset of luteal regression and oestrus in the normal oestrous cycle (Stabenfeldt, Akins, Ewing \& Morrissette, 1969; Henricks et al., 1972), after luteal enucleation (Anderson, Dyck \& Rathmaker, 1966) or after the cessation of methallibure treatment (Polge, 1965). In the cow (Lauderdale, 1972; Rowson et al., 1972) and the mare (Allen \& Rowson, 1973) oestrus occurs 2-4 days after PGF-2 $\alpha$ treatment.

The natural process of luteolysis may be a gradual one culminated by a surge of luteolytic substance late in the oestrous cycle. Gleeson \& Thorburn (1973) reported that PGF-2 $\alpha$ levels in the uterine veins of 3 sows increased from Days 11-14 of the cycle, preceding the decline in progesterone secretion, but morphological changes in the CL have been reported as early as Day 8 (Cavazos et al., 1969).

In practical terms, the use of prostaglandins alone for oestrous synchronization of gilts at various stages of the cycle seems severely limited because of the relatively short period of luteal sensitivity. The importance of luteal age in PGF-2 $\alpha$ mediated regression suggests that extension of the luteal phase followed by PGF-2 $\alpha$ treatment should be investigated as a method of oestrous synchronization in the pig.

We thank Imperial Chemical Industries Ltd for the ICI 79,939 and Mr D. E. Walters, A.R.C. Statistics Unit, for advice on the statistics.

\section{References}

AlleN, W.R. \& Rowson, L.E.A. (1973) Control of the mare's oestrous cycle by prostaglandins. J. Reprod. Fert. 33, 539-543.

Anderson, L.L., Dyck, G.W. \& Rathmaker, R.P. (1966) Pituitary gonadotrophic activities following luteal enucleation in the pig. Endocrinology 78, 897-900.

Anderson, L.L., Bland, K.P. \& Melampy, R.M. (1969) Comparative aspects of uterine-luteal relationships. Recent Prog. Horm. Res. 25, 57-104.

Cavazos, L.H., Anderson, L.L., Belt, W.D., Henricks D.M., KRaeling, R.R. \& Melampy, R.M. (1969) Fine structure and progesterone levels in the corpus luteum of the pig during the estrous cycle. Biol. Reprod. 1, 83-106.

Douglas, R.H. \& Ginther, O.J. (1972) Effect of prostaglandin $F_{2 \alpha}$ on length of diestrus in mares. Prostaglandins 2, 265 $\rightarrow 268$.

GiLl, J.L. \& HAFs, H.D. (1971) Analysis of repeated measurements of animals. J. Anim. Sci. 33, 331336.

Gleeson, A.R. \& Thorburn, G.D. (1973) Plasma progesterone and prostaglandin $F$ concentrations in the cyclic sow. J. Reprod. Fert. 32, 343-344.

Henricks, D.M., Guthrie, H.D. \& Handlin, D.L. (1972) Plasma estrogen, progesterone and luteinizing hormone levels during the estrous cycle in pigs. Biol. Reprod. 5, 210-218.

LAUDERDALE, J.W. (1972) Effects of PGF PG $_{2 \alpha}$ on pregnancy and estrous cycle of cattle. J. Anim. Sci. 35, 246, Abstr.

Liehr, R. A., Marion, G.B. \& Olson, H.H. (1972) Effects of prostaglandin on cattle estrous cycles. $J$. Anim. Sci. 35, 247, Abstr.

Louis, T.M., Hafs, H.D. \& Morrow, D.A. (1972) Estrus and ovulation after uterine $\mathrm{PGF}_{2 \alpha}$ in cows. J. Anim. Sci. 35, 247-248, Abstr.

Polge, C. (1965) Effective synchronization of oestrus in pigs after treatment with ICI compound 33828. Vet. Rec. 77, 232-236.

Rowson, L.E.A., Tervit, R. \& Brand, A. (1972) Synchronization of oestrus in cattle by means of prostaglandin. Proc. 7th Int. Congr. Anim. Reprod. \& A.I., Munich, Vol. II, pp. 865-869.

SeAmark, R.F., MOOR, R.M. \& MCINTOSH, J.E.A. (1974) Steroid hormone production by sheep ovarian follicles cultured in vitro. J. Reprod. Fert. 41, 143-158

Stabenfeldt, G.H., Akins, E.L., Ewing, L.L. \& MorrissetTe, M.C. (1969) Peripheral plasma progesterone levels in pigs during the oestrous cycle. J. Reprod. Fert. 20, 443-449.

Steel, R.G.D. \& Torrie, J.H. (1960) Principles and Procedures of Statistics. McGraw-Hill, New York. 